\title{
The Value and Symbol of Traditional Snack in Chinatown Gang Baru Semarang
}

\author{
Oktiva Herry Chandra* and Catur Kepirianto \\ Department of English Literature, Faculty of Humanities, Diponegoro University, Semarang - \\ Indonesia
}

\begin{abstract}
Traditional food displayed and sold in the traditional market Gang Baru Semarang does not mean as the way to meet the basic need for people living nearby the location. These foods may also function to fulfill spiritual manifestation of people that buy and use the food for celebrating festival, feast and ritual tradition. This article aims to explain the naming system, function and the symbol behind the various kinds of food in this market. The data were collected by observing the activity conducted the buyer and the seller. The writer also interviewd some of them to get additional information related to values and norms that make people serve tese foods. The results show that the naming system applied is based on the ingredient, shape and also the way they peoduce the food. Besides, these foods and cakes are also servede as media for performing a ritual traditionon for Chinese ethnic. Behind the name, there are some symbolic meaning which is believed as the manifestation of their belief to the values inhertited from their anchestors. The symbol is represented through the shape, the color and the number. Each of them pictures how this community see food and snack sold in traditional market located in Gang Baru Semarang..
\end{abstract}

Keywords: naming system, function, symbol, values, belief, and social interaction.

\section{Introduction}

Chinese community living in Semarang especially those who live in the neighborhood of Gang Pinggir considers traditional snack sold in traditional market may function not only as foodstuff to meet their daily basic need but also as facilities to perform ritual tradition. Chinese people have a tradition, festival, and ritual commemorated in special moment and specified date and month. Whenever a ritual is performed, they serve food and drink for the need of people involved in the celebration and for the need of the ritual.

In the context of global communication, traditional snacks has its strategic role as media for introducing specified culinary from Semarang city and for promoting tourism destination picturing the cultural values from various ethnic group living side by side in

\footnotetext{
* Corresponding author : herrychandra@gmail.com
} 
friendly atmosphere. Traditional snacks lately empower the economic potential and increase the participation of its citizen in improving the quality of living in Semarang.

Local and traditional nuance holds its phenomenal and strategic media for introducing and maintaining cultures and traditions in Semarang. This traditional food comes from the tradition of Chinese families that have a habitual activities of gathering. During the time, they will serve various kinds of food and snacks. They believe eating for them is symbolizing an honor to people joining the gathering and their anchestor. The food served on the table is not merely for those who are still living but it is also dedicated to the spirit of their prior generation. Western culture symbolizes happiness by saying with flower, while Chinese people express their happiness by saying with food. When meeting people, the first question is have you eaten yet? Different nation has different ways for expressing happiness and honor. That is why studying food especially traditional snacks sold in Chinese neighborhood is an interesting object.

This article aims to figure out the classification of foodstuff's name, the function of these traditional snacks and the symbol behind the food.

\section{Methodologies}

The researcher used non-participatory observation method in collecting data. This method was accompanied by two others technique, namely note taking technique and recording. By using these methods, the researcher collected data; writings containing prohibition for not littering garbage and maintenance for the cleanliness of the environment displayed in open space area.. These data were gained in several different locations in Semarang. Interview was also implemented to figure out the motivation behind the making such writings. The data processing was done by classifying and grouping data. This was followed by analyzing data.

This research has been carried out and reached several stages of research. The stages of research that have been done are pre-research in the form of observation, field research collecting data, processing and classification of data, and analysis of research data.

There are several stages in order to be able to gather the data. The reseacher at the preresearch stage conducted non-participatory observation. In this level, the information were gathered by observing the activities of people visiting Chinatown market and the traditional snack being sold in the market. The information was gained from the transaction of speeches between sellers and buyers. The information gathered occupies the name of the food, the use and the symbol behind the shape, color and number. Beside this method, the researcher also carried out the data collection by interviewing the sellers and buyers. The interview was focussed on the names of traditional snacks and the reasons for selling and buying traditional snacks. After the data were collected comprehensively, the researcher classified the name of traditional snack based on the pattern number of the names. Research data were also analyzed to determine the function and symbol of traditional snakcs in ritual or non-ritual activities. The result of data analysis was presented to describe the names, naming systems, symbol and the function of traditional snacks in Chinatown, Semarang.

\section{Heoretical Framework}

The researcher refers to some literatures that has already discussed the related topics. This study refers to Hayakawa, S.I. 2009. "Symbols" [1]; Berlin, B., D.E. Breedlove \& P.H. Raven. 1973. "General Principles of Classification and Nomenclature in Folk Biology" [2]; Danesi, M. 2011. Messages, Signs, and Meaning: A Basic Textbook in Semiotics and 
Communication Theory [3]. These are used to classify the names of traditional snacks found in the traditional market Gang Baru. While the others sources such as Cahyono, D. 2000.”Pelestarian Makanan Tradisional melalui Industri Pariwisata" [4]; Haryono, T. 1997. "Makanan Tradisional dari Kajian Pustaka Jawa" [5]; Kartodirjo. 1995. Unsur Makanan dalam Sistem Budaya Jawa di Kotamadya Surakarta [6] are used as a comparison to the kinds of traditional food existing in Central Java and as the enrichment to the culinary tourism in general.

This study also used the book written by Kramsch, Claire. 1998. Language and Culture [7]; articles written by Marsono, T. Haryono, D. Winarti, dan Suparmo. 1998. "Makanan Tradisional dalam Serat Centhini" [8]; Moertjipto, J.S. Rumijah, Moeljono, dan J.Astuti. 1994. Makanan: Wujud, Variasi, dan Fungsinya, serta Cara Penyajiannya pada Orang Jawa Daerah Istimewa Yogyakarta[9]; Moertjipto dan A. Adrianto. 1995. "Jajan Pasar dalam Tradisi Kraton Yogyakarta"[10]. For the interest of classification, the book written by Nida, E.A. 1975. Componential Analysis of Meaning: An Introduction to Semantic Structures is applied [11]. And this is proceeded by the use of articles written by Suhandano. 2000. "Klasifikasi Folk Biologi dalam Bahasa Jawa: Sebuah Pengamatan Awal"[12]; Sulaiman, L.S. 1993. "Jajan Pasar dan Pariwisata Indonesia" [13]; Suwandi. 1999. "Jenis Makanan dan Minuman Tradisional dalam Naskah di Perpustakaan Sana Budaya Yogyakarta dan Sana Pustaka Surakarta"[14]; Wahjono, P. 2010. "Nilai Filosofis Makanan Tradisional dalam Kaitannya dengan Adat Istiadat Jawa"[15]; Widada, 2007. "Istilah Makanan Tradisional dalam Bahasa Jawa"[16]. For enriching the reference to the culture point of view, the researcher used the book of Wierzbicka, A. 1997. Understanding Cultures through Their Key Words: English, Russian, Polish, German, and Japanese [17].

Compared to some studies that have been conducted by some researchers, the research on naming system, function and symbolization behind the naming system of traditional food being offered and sold in traditional market Gang Baru in Semarang lies some differences which reflect cultural values and norms internalized in multi etnic community in Semarang.

\section{Finding and Discussion}

\subsection{Naming System}

From the collected data which expose the name of traditional food displayed and sold in Gang Baru traditional market, at least there tree classification that might be proposed, namely ingrediant, shape and method. These three elements are mostly found in the system of naming traditional food. Based on the ingredient used in making this tradtitional food, there are several names of food of which people will be able to guess the taste of the food by looking at the name. People in Chinatown are very familiar with some foods, namely Bakcang, Bakpao, Lunpia, and Lopis Ketan. Chinese food bakcang and bakpao used to be made of pig meat as the main ingredient. In Chinese, word bak means pig meat. There various kinds of Chinese food made of pig meat, but the most famous buns in Semarang are bakcang and bakpao. Bakcang (bacang) is made of glutinuos rice wrapped in bamboo leaves and shaped into a diamond and filled with meat and steamed. Nowdays, this food is mostly filled with beef and mutton or lamb. The replacement of the content is for the shake of accomodating those who believe that pig meat is forbiden to consume. In this sense, the change is also reflecting a cultural acculturation between two ethnics, namely Javanese and Chinese and religions, that is Moslem and Kong Hu Chu. Meanwhile, bakpao(meatbun) is made of wheat flour shaped like polygonal and filled with meat as well. From its name, Lopis ketan (glutinuous rice) is a traditional food made of sticky or glutinuous rice 
wrapped in banana leaves, shaped like a pipe and steamed. This food is served with grated coconut and brown sugar.

Traders in Gang Baru also name their traditional food based on the the shape. There are some foods representing the shape, such as Jiaozi, Lapis, Ang Ku Kue, Tiong Ciu Pia, and Ganjel Rel. The name of Ang Ku Kue is taken as the shape of the food is identical to turtle. Ang ku kue in China means turtle. Thia animal is considered as an animal that is blessed for having long lived. Chinese hope that they will be blessed and will be able to enjoy their eternal life if possible. The name of Tiong ciu pia is given as the shape of this food is round like a moon. People also name this food as "moon cake" since the shape resembles the moon. The food is called lapis as there so many layers in the cake. The number of the layers depends on the lucky that people want since the more layer they have they believe the more opportunity they have. The name of ganjel rel is also based on the same reason, that is, the shape of the cake is identical to railroad. This food is only produced in Semarang and also distributed in limited area.

The last naming system in traditional food in Chinatown Gang Baru lies on the way the food is made. From this naming, Semarang is well known as the producers several kinds of food such as Kue Cucur, Kembang Goyang, ting Ting Gepuk, and Dadar Gulung. The cake is named Kue Cucur since during the process of making this cake, the cook pours the batter for the cake. The batter is a mixture of rice flour and brown sugar. This ingredient, then, is added with some water, and stirred. This mixture is poured into hot cooking oil. Here, the word cucur means pouring. Additionally, the cake is named Kembang Goyang as the cook shakes the batter to make it get released from the cookie mold. The batter is also given with various color. Kembang means colorfull. Ting ting gepuk is given the name since during the proses of making this cake, the cook has to pound (gepuk) the batter which is made of the mixture of brown sugar and peanut. This is pounded to make it get hard and shaped it into bar or diamond. The similar process happens during the making of Dadar Gulung. The cake is made by rolling the batter and is steamed after.

\subsection{Function of The Food}

From the collected data which expose the name of traditional food, Chinese in Semarang make use the food and cake as media when performing a ritual or celebrating the very special day. For example, Chinese New Year ( $\mathrm{Sin} \mathrm{Cia}$ ) celebrations, Imlek, the new year for the Chinese community is celebrated by serving kue keranjang (nian gao), kue mangkok merah, and lontong cap go meh held on the 15th day of Chinese New Year. On ancestral prayer days, people living in Chinatown Semarang provide 3 kinds of cake. At the time of Peh Cun, they eat bakcang (sticky rice combined with chopped pork meat wrapped in bamboo leaves, shaped into a diamond and steamed). Meanwhile, on celebrating Tiong Jiu they eat kue bulan "moon cake" (Tiong Jiu Pia). This tradition has been done for thousands of years.

Chinese society love eating together and it becomes a tradition. Relatives gather to strengthen brotherhood among the family members. One thng that they do not forget is that they first devote the food to ancestors as an ethic to their predecessors. They are praying as gratitude to the Creator with the emergence of new years and new hopes. Various foods, fruits and drinks are served, such as kue keranjang, kue lapis, kue mangkok, and mie panjang (siu mi). Long noodles (siu mi) are mandatory and favorite dishes as well. Fish is a dish that means abundant fortune, while fish salad is believed to be a dish that gives good luck. Balinese and mandarin oranges are the most favourite fruit for the tradition. These fruits are choosen as the color symbolizes a good fortune for their lives.

The Chinese New Year, Cap Go Meh, is a celebration held on the $15^{\text {th }}$ day by enjoying special food, namely lontong Cap Go Meh as a symbol of the full moon and togetherness. 


\subsection{Symbol of The Food}

The life and hope among members of Chinatown of Semarang are symbolized in three elements, they are shape, color and number. These are implemented in every kind of cake and fruit they consume and serve for special moment, such as festival, celebration, and ritual. Even, they try to meet these three elements when they consume the food for fulfilling their basic needs.

The shape of food is formed to resemble several entities in the world, namely animal, circle and ship. The animal is one of symbols that they believe as representation of ever lasting life. They ensure turtle is a long lived animal and is able to get through their life more than thousand years. This animal is able to overcome problems of life because of its patience in facing the up and down of life. Even, this animal lives in colony and supports the member of their circumstances. Togetherness and support from others make this colony be able to undergo the life peacefully. By making the food resembling this creature, Chinese ethnics hope they will be blessed for living longer and be able to live side by side with others in a supportive environment. This animal is also well known as a tough creature and is able to protect themselves from their enemy. Its skull protects the body from the offense of its enemy. The cook usually takes this body part as the shape of the food. The cake Ang Ku Kue immitates the shape of turtle.

Circle is also favourite to Chinese. This shape symbolizes never ending fortunes. There is no end in this type of cake. It means they will always be given good fortunes and be able to maintain their prosperity. Basket cake (Kue keranjang) is one of the examples. This food is made of sugar and the flour of sticky rice. Sticky rice is taken as the ingredient as this is used to tell people how important togetherness and closeness are to this ethnic. Brotherhood is very important to this great family and is proved by living nearby event though they have make their own family. They also hold a routine meeting among the members of family weekly, monthly or yearly. This food is usually served as they celebrate lunar new year or imlek. Eating this food symbolizes the hope of the higher year; a better future. This sticky cake symbolizes as well a wise advice for keeping their mouth stick together for not mentioning the bad attitude of others.

The shape resembling ship means prosperity. This shape imitates the form of ship which is identical to the silver coin as media for transaction in the past. The food resembling this shape is dumpling (pangsit). Consuming dumpling means prosperity and welfare will come to their life and family. The more they consume, the better their fortune will be in future.

Color is also essential to people living nearby Gang Baru Semarang. Traditional foods are dominated by yellow and red color. Red color (hong) gives meaning to bravery, happiness, spirit, and luck. Yellow color represents prosperity, loyalty and purity. The combination of these two colors symbolize the balance between yin and yang. Yin represents negative force, while yang means positive one. According to the concept of Chinese world, their life will be blessed as long as they are able to maintain this two opposite forces. These forces are complementary, interconnected and interdependent. In real world, these should be made to make rise each other as they are interrelated one to another. The choice of the color doesn't belong to the food, this also happen to kids of fruits sold in the market Gang Baru. The seller displays fruits which are dominated by red and yellow color. Dragons fruit and Sunkis orange dominate the basket of display since naturally these two are red and yellow in color. Water melons are also sold in this market because of the color they have. People will find no difficulties in finding these fruits in their stall.

Number is also considered bringing good luck for the life of this ethnic. They believe number 9 will make them live longer and even eternity. When they are praying in the temple they are accompanied by many kinds of food and fruits. Additionally, they will 
make sure that the number of each ritual offerings consists of 9 elements. The number is also no more and less than 9. By doing so, the pray will be blessed and they will be able to enjoy their life in long term. The number 8 also brings them into a never ending prosperity, luck and welfare. Number 8 is written with no end character. as it is pronounced it sounds $f a$ which means wealth or fortune. As Chinese have to serve food in a basket or bowl, they prefer to choose the octagonal one. They will also choose their phone number which contain this number. Even, when the are going to stay in hotel they will choose the room number containing number 8 . They may choose the room number $08,18,28,38$ or 88 . They deeply belief this number gives them good lucks and fortunes.

\section{Conclusion}

A proverb in China "Food is the foremost", Min Yi Shi Wei Tian. Food has a very important meaning to Chinese people. Even, they are ready to suffer as long as they can eat. According to the Chinese teachings, one grain of rice has a high value and meaning and it should not be wasted because no one grain of rice comes easily.. Throwing or wasting food is the same as doing karma or sin. The neccesity of food in the life of these people are also represented by naming system, function and symbols. Food for them is not merely the need for supporting their life. It also is the representation of value, norm and way of life.

\section{Acknowledgements}

In this good opportunity, the writer would address his deepest gratitude to the Dean of Humanities Faculty, Diponegoro University who has given this great opportunities being involved and sponsored this scheme research program.

\section{References}

1. Hayakawa, S.I. Komunikasi Antarbudaya: Panduan Berkomunikasi dengan OrangOrang Berbeda Budaya (2009)

2. Berlin, B., D.E. Breedlove \& P.H. Raven.. Am. Anth. 75 (1), 214-242 (1973)

3. Danesi, M. . Messages, Signs, and Meaning: A Basic Textbook in Semiotics and Communication Theory. Canadian Scholars' Press Inc (2011)

4. Cahyono, D.. Seminar Nasional Makanan Tradisional di Malang, 26 Februari. (2000)

5. Haryono, T. Sarasehan dan Pameran Makanan Tradisional dalam Pandangan Budaya dan Keamanannya. Yogyakarta: PKMT UGM. (1997)

6. Kartodirjo.. Unsur Makanan dalam Sistem Budaya Jawa di Kotamadya Surakarta. Laporan Penelitian Universitas Negeri Sebelas Maret. (1995)

7. Kramsch, Claire.. Language and Culture. Oxford: Oxford University Press. (1998)

8. Marsono, T. Haryono, D. Winarti, dan Suparmo.. Pusat Kajian Makanan Tradisional (PKMT) UGM dan Badan Urusan Logistik Proyek Peningkatan Ketahanan dan Keamanan Pasar. (1998)

9. Moertjipto, J.S. Rumijah, Moeljono, dan J.Astuti.. Makanan: Wujud, Variasi, dan Fungsinya, serta Cara Penyajiannya pada Orang Jawa Daerah Istimewa Yogyakarta. Yogyakarta: Depdikbud (1994). 
10. Moertjipto dan A. Adrianto. Makalah dalam Diskusi, Lomba, dan Festival Jajan Pasar Tradisional yang Diselenggarakan oleh Menpangan Bekerja Sama dengan PSW UGM, FTP UGM, dan Ikaboga DIY. (1995)

11. Nida, E.A. Componential Analysis of Meaning: an Introduction to Semantic Structures. The Hague, Paris: Mouton. (1975)

12. Suhandano. Humaniora XII, 225-230 (2000)

13. Sulaiman, L.S.. Penerima Adikarya Pariwisata RI (1993)

14. Suwandi.. Seminar Nasional Makanan Tradisional (1999)

15. Wahjono, P. Pentas Ilmu di Ranah Budaya:

Sembilan Windu Prof. Dr. Edi Sedyawati. Bali: Pustaka Larasan. 145--160 (2010)

16. Widada, Budaya Jawa dalam Kata. 21--26 (2007)

17. Wierzbicka, A.. Understanding Cultures through Their Key Words: English, Russian, Polish, German, and Japanese. Oxford and New York: Oxford University Press. (1997) 